\title{
Quantitative relation between emphysema and lung mineral content in coalworkers
}

\author{
James Leigh, Timothy R Driscoll, Bradley D Cole, Rolf W Beck, Brynley P Hull, \\ Jihong Yang
}

\begin{abstract}
The relation between quantified emphysema and measured lung content of coal and silica was investigated in the lungs of 264 deceased underground coalworkers who had been exposed to mixed coal and silica dust. Lung specimens obtained at postmortem and inflated and fixed under standard conditions were used to quantify the extent of emphysema and then to measure the amount of coal and silica present in the lungs at the time of death. These data were combined with clinical and other pathological information from the subjects. Multiple regression analysis showed that the extent of emphysema ( $E$ score) had a strong positive quantitative relation with coal content of the lungs ( $p$ $<0.0003)$, age $(p<0.0001)$, and smoking $(p<0.0001)$. There was a significant negative interaction of uncertain biological importance between coal content of the lungs and smoking ( $p<0.004 ; E$ score = $-1.79+0.62$ coal +0.06 age +0.21 smoking -0.17 coal $\times$ smoking; adjusted $R^{2}=$ 0.25). In lifelong non-smokers emphysema was particularly strongly related to coal content and age (coal: $p<0.001$; age: p $<0.002 ; E$ score $=-1.56+0.78 \mathrm{coal}+$ 0.06 age; adjusted $\left.R^{2}=0.66\right)$. The relation was basically unchanged by adding a lung silica content term. Emphysema score was highly negatively correlated with forced expiratory volume in one second $\left(F_{1}\right.$; \% predicted, obtained within five years of death $)(r=-0.44, p<0.0001)$. Degree of lung fibrosis was highly positively associated with lung silica content $\left(\chi_{1}{ }_{1}=12.9, \quad \mathrm{p}<0.0003\right)$. These results provide strong evidence that emphysema in coalworkers is causally related to lung coal content. The role of silica in development of emphysema, however, remains unclear.
\end{abstract}

\section{(Occup Environ Med 1994;51:400-407)}

The relation of emphysema to coal dust and silica dust content in the lungs of coal workers exposed to mixed dust remains controversial, despite considerable recent research. ${ }^{1-6}$ Well designed large studies on postmortem pathological material have shown that emphysema, especially centriacinar emphysema, is qualitatively related to the coal dust content of lungs $^{7-9}$ and quantitatively related to severity of pneumoconiosis, years at the coal face, and indices of obstructive lung disease obtained during life. ${ }^{1011}$

Previous workers have found an association between prevalence of emphysema and coal content of the lungs ${ }^{7-9}$ but not between extent of emphysema and measured coal content. In a hospital based case-control study, Cockcroft et $a l$ found an excess of emphysema in coalworkers compared with non-coalworkers, and an association between severity of emphysema and dust exposure. The dust exposure score was, however, based on pathological assessment of lung specimens rather than on measured lung dust content or exposure measurements. Ruckley et al showed a clear relation between the presence of centriacinar emphysema and higher coal dust exposures (whether as inhaled dust or lung content of dust), but were unable to find a relation between the amount of emphysema and exposure to coal dust. They suggested that this may have been due to problems with lung inflation and tissue fixation or an indication that coal initiates the emphysema but other factors influence its progression. ${ }^{89}$

Recent studies of coalworkers have suggested that emphysema is relatively less likely with high lung silica content. ${ }^{912}$ By contrast, emphysema is related to exposure to silica dust in goldminers. ${ }^{1314}$

Estimation of the relation between emphysema and exposure to coal dust by evaluating pneumoconiosis pathologically is potentially biased because the coal dust lesions draw attention to the emphysema. This can be partly avoided by the use of radiological pneumoconiosis scores. ${ }^{11}$ The radiological appearances may not, however, be due to coal. The most objective exposure index, not subject to these biases, is actual coal content of the lungs.

Underground coalworkers in the New South Wales (Australia) coal industry are exposed to high rank bituminous coal (\% carbon dry ash free $82 \%-90 \%$ ). Silica content of the New South Wales coal seams is on average less than $2 \% .{ }^{15}$ Some workers would have been exposed to higher silica levels when working in shaft development and in other mines, predominantly in the United Kingdom. Some of these workers would have been exposed to much higher dust levels than those obtaining today.

The aim of this study was to determine the relation between quantified emphysema and measured lung content of coal dust and silica dust in coalworkers. 


\section{Methods}

The data analysed in this study came from workers in the New South Wales coal mining industry who died during the period July 1966 to January 1983. The New South Wales Joint Coal Board, with the assistance of relevant unions, has encouraged the conduct of postmortem examinations on all deceased coalworkers since 1949. The proportion of coalworkers who underwent postmortem examinations is probably influenced by a number of factors, including perceived eligibility for compensation. The 264 subjects included in this study represent $70 \%$ of the 376 coalworkers (all male) who underwent postmortem examination during the study period. Inadequacy of lung specimens was the main reason for exclusion of subjects. Other subjects who were excluded from the analyses had missing data. Subjects who underwent a postmortem examination consisted of about $20 \%$ of all coalworkers who died during the study period (based on the New South Wales annual male crude death rate of $9 \cdot 6 / 1000$ in 1972 and a mean mining population of 14000 over the study period).

\section{TISSUE PREPARATION}

After removal from the body, both lungs were perfused immediately with $10 \%$ acetate formalin via vessels and bronchi under a pressure of $120 \mathrm{~cm}$ water without any vessels or airways tied off, until the lungs were inflated to a volume between functional residual capacity and total lung capacity. The lungs were stored in $10 \%$ formalin in plastic containers.

Blocks for histology were taken from each lobe of each lung and from hilar lymph glands. In 35 subjects, Gough-Wentworth large lung sections ${ }^{16}$ were made of the left lung, with a $2 \mathrm{~cm}$ thick sagittal slice involving the hilar region.

\section{MEASUREMENT OF EMPHYSEMA AND}

\section{PNEUMOCONIOSIS}

Emphysema was quantified by one of two observers by a modification of the Heard method. ${ }^{17}$ This was done on macroscopic examination of the surfaces of at least three cuts in the sagittal plane in each lung. Each cut was divided into three segments of roughly equal area. In each segment the percentage of lung area involved as abnormal holes was measured and the mean for each of the three or more cuts was calculated. Both fixed and Gough-Wentworth sections were used. When both types of sections were available for the same subject, the emphysema estimations agreed closely. The mean for all the cuts from both lungs became the final percentage emphysema score. This was then coded 1-7 (1 nil; $21-10 \% ; 311-20 \% ; 421-$ $30 \%$; 5 31-40\%; $641-50 \%$; $7>50 \%$ ). There was good agreement shown between the two observers for separate readings of 400 lungs by this method. ${ }^{11}$

Classification of pneumoconiosis was made on the basis of macroscopic and microscopical examination of lung tissue and an examination of whole lung sections. Macules and nod- ules were classed as sparse (equivalent to International Labour Office (ILO) 1/0 or less), moderate (less than ILO $2 / 2$ ), or profuse (ILO $2 / 2$ or greater), and massive lesions documented. Distinction was made between coal only (macules), mixed coal and silica (nodules, palpable), and silica only changes. One observer made all classifications. Pneumoconiosis classification was available for 259 (98\%) subjects.

\section{ANALYSIS OF LUNGS FOR COAL AND SILICA}

CONTENT

Specimens were freed of non-lung tissue, cut into pieces of about $2 \mathrm{~cm}^{3}$, homogenised in a blender, dried on shallow trays at $105^{\circ} \mathrm{C}$ in a laboratory oven, and ground in a mill to pass a $0.5 \mathrm{~mm}$ screen, giving an average particle size of $200 \mu \mathrm{m}$. Lungs had been previously dissected at necropsy and no attempt was made to further separate lymphatic tissue. Tissue used for preparation of large lung sections was included.

Powdered lung samples were hydrolysed with a modified version of the procedure of Guest. ${ }^{18}$ Subsamples of the powdered lung (1 g) were hydrolysed in duplicate in screw capped polypropylene centrifuge tubes by heating with shaking for two hours at $60^{\circ} \mathrm{C}$ with concentrated hydrochloric acid $(20 \mathrm{ml}$, $36 \%)$. The hydrolysis procedure was carried out three times. Each hydrolysis step was followed by dilution with ethanol $(20-25 \mathrm{ml})$, separation of the solid residue by centrifuging (30 minutes, $3000 \mathrm{rpm}$ ), and careful siphoning off of the hydrolysis product (supernatant). The separated residue was repeatedly washed with ethanol and centrifuged as before, until the supernatant was clear (usually two to three washes).

The slurried residue in the centrifuge tube was transferred quantitatively to a preweighed platinum crucible with ethanol and toluene. Total lung dust, total coal, and total mineral matter (ash) were determined gravimetrically: the total lung dust after first drying the crucible contents at $110^{\circ} \mathrm{C}$, the total mineral matter after ashing the crucible contents at $600^{\circ} \mathrm{C}$ overnight, and the total coal by calculating the difference between total lung dust and total mineral matter. Finally, silica (quartz) was determined in the ash by Fourier transform infrared spectroscopy with the potassium bromide disc technique $(1 \mathrm{mg}$ ash per $250 \mathrm{mg}$ disc), essentially by the method of Dodgson. ${ }^{19} \mathrm{By}$ ashing at $600^{\circ} \mathrm{C}$ we obtained less interference in the quartz spectra at the expense of not being able to quantitatively determine kaolin and mica. The main results consider the total amount of coal and silica in the two lungs of each subject, standardised by predicted vital capacity (from height and age) ${ }^{20}$ For comparison purposes results were also expressed as proportions of coal or silica by dry weight of lung and as absolute amounts of coal and silica.

\section{SMOKING HISTORY}

Data on smoking history were obtained from a standardised questionnaire given at Joint 
Table 1 Means (SD) and percentiles of main variables

\begin{tabular}{|c|c|c|c|c|c|}
\hline & \multirow[b]{2}{*}{ No } & \multirow[b]{2}{*}{$\operatorname{Mean}(S D)$} & \multicolumn{3}{|c|}{ Percentiles } \\
\hline & & & $25 \%$ & $50 \%$ & $75 \%$ \\
\hline $\begin{array}{l}\text { Emphysema score } \\
\left.\text { Adjusted lung coal content }(\mathrm{g} /)^{\star}\right)^{\star} \\
\text { Absolute lung coal content }(\mathrm{g}) \dagger \\
\text { Adjusted lung silica content }(\mathrm{g} / \mathrm{l}) \star \\
\text { Absolute lung silica content }(\mathrm{g}) \dagger \\
\text { Tobacco smoked (ounces/week) } \\
\text { Age at death (y) } \\
\text { FEV } \% \ddagger\end{array}$ & $\begin{array}{l}264 \\
264 \\
264 \\
261 \\
261 \\
264 \\
264 \\
183\end{array}$ & $\begin{array}{l}3 \cdot 1(1 \cdot 5) \\
0 \cdot 89(0 \cdot 81) \\
3 \cdot 93(3 \cdot 44) \\
0 \cdot 04(0 \cdot 04) \\
0 \cdot 18(0 \cdot 17) \\
3 \cdot 1(2 \cdot 2) \\
63 \cdot 4(10 \cdot 4) \\
78 \cdot 7(25 \cdot 5)\end{array}$ & $\begin{array}{l}2 \\
0 \cdot 32 \\
1 \cdot 53 \\
0 \cdot 02 \\
0 \cdot 08 \\
2 \\
58 \\
60\end{array}$ & $\begin{array}{l}3 \\
0 \cdot 65 \\
2 \cdot 88 \\
0 \cdot 03 \\
0 \cdot 12 \\
3 \\
64 \\
81\end{array}$ & $\begin{array}{l}4 \\
1 \cdot 21 \\
5 \cdot 07 \\
0 \cdot 05 \\
0 \cdot 21 \\
4 \\
71 \\
98\end{array}$ \\
\hline
\end{tabular}

^Adjusted by predicted vital capacity.

†Absolute amount of lung coal or silica per subject.

$\ddagger$ Measured FEV , as a percentage of predicted (using height and age). ${ }^{20}$

Coal Board routine clinical examinations, which were held every two to three years. Smoking was expressed as ounces of tobacco smoked per week ( 1 ounce $=28 \mathrm{~g}$ ), based on a lifetime average of tobacco intake.

\section{LUNG FUNCTION MEASUREMENTS}

Forced expiratory volume in one second $\left(\mathrm{FEV}_{1}\right.$; body temperature, atmosphere pressure, and saturation) was measured with a Vitalograph spirometer and the results were recorded as the higher of two satisfactory efforts. The measurements were performed at the routine clinical examinations. Measurements were only accepted for this study if taken within five years of death. Results were available for $183(69 \%)$ miners. Values were expressed as percentage predicted $\left(\mathrm{FEV}_{1} \%\right) .{ }^{21}$

\section{YEARS AT FACE}

Information on years worked at the coal face was obtained from the detailed occupational histories taken at each routine Joint Coal Board clinical examination.

\section{STATISTICAL METHODS}

Calculations were performed with standard simple parametric and regression techniques as programmed in the Statistical Analysis System, ${ }^{22}$ with appropriate checking of residuals in regression models. Statistical significance was determined at the $5 \%$ level (two sided).

\section{Results}

Table 1 gives the frequency distributions, means, SDs, and quartile values for emphysema score, lung coal content, lung silica content, smoking amount, age at death, and $\mathrm{FEV}_{1} \%$. Age, smoking, and $\mathrm{FEV}_{1} \%$ had normal distributions, with similar medians and means. By contrast, the lung dust content

Table 2 Distribution of pneumoconiotic changes

\begin{tabular}{llllll}
\hline \multicolumn{7}{l}{ Pneumoconiosis severity } \\
\cline { 2 - 6 } $\begin{array}{l}\text { Pneumoconiosis } \\
\text { type }\end{array}$ & Sparse & Moderate & Profuse & Massive & Total \\
No(\%) & No(\%) & No(\%) & No(\%) & No(\%) \\
\hline Coal & - & $72(28)$ & $10(4)$ & $4(2)$ & $86(33)$ \\
Mixed & - & $29(11)$ & $11(4)$ & $6(2)$ & $46(18)$ \\
Silica & - & $4(2)$ & - & - & $4(2)$ \\
Sparse & $123(47)$ & - & - & - & $123(47)$ \\
Total & $123(47)$ & $105(40)$ & $21(8)$ & $10(4)$ & $259(100)^{\star}$ \\
\hline
\end{tabular}

* 5 subjects did not have data regarding pneumoconiotic change. Errors in total percentages are due to rounding.
Table 3 Mean coal and silica content by type of pneumoconoisis

\begin{tabular}{|c|c|c|}
\hline \multirow[b]{2}{*}{$\begin{array}{l}\text { Pneumoconiosis } \\
\text { type }\end{array}$} & \multicolumn{2}{|c|}{$\begin{array}{l}\text { Lung content } \\
\text { (g/l predicted vital capacity) }\end{array}$} \\
\hline & $\begin{array}{l}\text { Coal` } \\
\text { Mean(SD) }\end{array}$ & $\begin{array}{l}\text { Silica† } \\
\text { Mean(SD) }\end{array}$ \\
\hline $\begin{array}{l}\text { Sparse }(n=123) \\
\text { Coal }(n=86) \\
\text { (moderate, profuse, massive) }\end{array}$ & $\begin{array}{l}0.53(0.41) \\
1.15(0.84)\end{array}$ & $\begin{array}{l}0.03(0.02) \\
0.05(0.03)\end{array}$ \\
\hline $\begin{array}{l}\text { Mixed ( } n=46 \text { ) } \\
\text { (moderate, profuse, massive) }\end{array}$ & $1 \cdot 41(1 \cdot 11)$ & $0.07(0.06)$ \\
\hline
\end{tabular}

*Mean lung coal content significantly different for each group ( $F=31.8, p<0.0001$ ) by Duncan's multiple range test tMean lung silica content significantly different for each group $(\mathrm{F}=30 \cdot 6, \mathrm{p}<0.0001)$ by Duncan's multiple range test.

variables and emphysema score were positively skewed.

Excluded subjects had a similar mean emphysema score ( $3 \cdot 1)$, age (67 years), smoking amount ( $3 \cdot 1$ ounces/week), $\mathrm{FEV}_{1} \%(74 \%$ predicted), and years worked at the coal face (21) as subjects included in the analyses. Subjects without $\mathrm{FEV}_{1}$ data had a higher mean emphysema score $(3.6 v 2.8)$, higher mean lung coal content ( $1.25 \quad v \quad 0.73 \mathrm{~g} / \mathrm{l})$, higher mean lung silica content $(0.051 v$ $0.037 \mathrm{~g} / \mathrm{l}$ ), and were older (67 $v 62$ years), but had smoked a similar amount $(2.9$ vs 3.2 $\mathrm{oz} /$ week) and had worked a similar number of years at the coal face $(21 v 19)$ as subjects with $\mathrm{FEV}_{1}$ data.

Most subjects had minimal or mild pneumoconiotic changes and there were only four with silica only changes (table 2). Mean coal and silica content in the lungs were highest in those subjects with a mixed pneumoconiosis, next highest in those subjects with primarily coal pneumoconiosis, and lowest in subjects with minimal changes. All differences were statistically significant (table 3 ). Lung fibrosis was highly significantly related to lung silica content $(p<0.005)$ and age $(p<0.0001)$ but not to lung coal content $(p>0.55)$ when examined in the same model by logistic regression.

The distribution of emphysema score was positively skewed, suggesting that a log transformation might be appropriate for regression techniques. Results from the regression equations were similar, however, with and without transformation. A slightly better fit was obtained when the log transformation of emphysema score was used. Residuals were appropriately distributed whether the emphysema score or its logarithm was used as the outcome variable. For clarity, only the analyses with the untransformed emphysema score are presented. Table 4 shows the correlation matrix for variables of interest.

Emphysema score (E score) increased significantly with coal content of the lungs, age, and amount of smoking (equation 1).

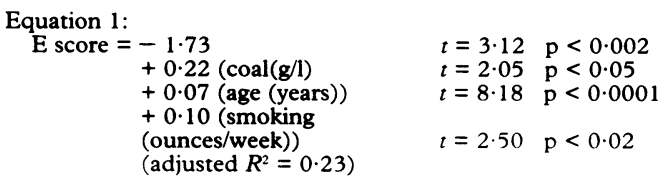

Silica content of the lungs did not contribute significantly to the model. Addition of a 
Table 4 Correlation matrix of main variables (Pearson correlation coefficient ( $r$ ))

\begin{tabular}{|c|c|c|c|c|c|c|c|}
\hline & $\begin{array}{l}\text { Emphysema } \\
(n=264)\end{array}$ & $\begin{array}{l}\text { Coal } \\
(n=264)\end{array}$ & $\begin{array}{l}\text { Silica } \\
(n=264)\end{array}$ & $\begin{array}{l}\text { Age } \\
(n=264)\end{array}$ & $\begin{array}{l}\text { Smoking } \\
(n=264)\end{array}$ & $\begin{array}{l}\text { Years at face } \\
(n=264)\end{array}$ & $\begin{array}{l}F E V_{1} \% \\
(n=183)\end{array}$ \\
\hline Emphysema & 1.00 & & & & & & \\
\hline Coal & $0 \cdot 20^{\star \star}$ & 1.00 & & & & & \\
\hline $\begin{array}{l}\text { Silica } \\
\text { Sil/) }\end{array}$ & $0 \cdot 19^{\star \star}$ & $0.54^{\star \star \star \star}$ & 1.00 & & & & \\
\hline $\begin{array}{l}\text { Age } \\
\text { (v) }\end{array}$ & $0 \cdot 46^{\star \star \star \star}$ & $0 \cdot 23^{\star \star \star}$ & $0 \cdot 26^{\star \star \star \star}$ & 1.00 & & & \\
\hline $\begin{array}{l}\text { Smoking } \\
\text { (ounces/week) }\end{array}$ & 0.04 & $-0 \cdot 15^{\star}$ & $-0 \cdot 25^{\star \star \star \star}$ & $-0 \cdot 17^{\star \star}$ & 1.00 & & \\
\hline $\begin{array}{l}\text { Years at face } \\
\mathrm{FEV}_{1} \%\end{array}$ & $\begin{array}{r}0 \cdot 24^{\star \star \star \star \star} \\
-0 \cdot 44^{\star \star \star \star}\end{array}$ & $\begin{array}{l}0.27^{\star \star \star \star} \\
-0.01\end{array}$ & $\begin{array}{l}0.26^{\star \star \star \star} \\
0.05\end{array}$ & $\begin{array}{r}0 \cdot 45^{\star \star \star \star \star} \\
-0 \cdot 31^{\star \star \star \star}\end{array}$ & $\begin{array}{l}-0.19 \star \star \\
-0.02\end{array}$ & $\begin{array}{r}1 \cdot 00 \\
-0 \cdot 11\end{array}$ & 1.00 \\
\hline
\end{tabular}

Table 5 Regression parameters for various measures of lung coal content

\begin{tabular}{|c|c|c|c|c|c|c|}
\hline \multirow[b]{3}{*}{ Parameter } & \multicolumn{6}{|c|}{ Measure of coal used in final regression equation } \\
\hline & \multicolumn{2}{|c|}{ Adjusted by vital capacity } & \multicolumn{2}{|c|}{ Proportion of lung dry weight } & \multicolumn{2}{|c|}{ Absolute amount per subject } \\
\hline & t Value & $p>|t|^{*}$ & $t$ Value & $p>|t|^{*}$ & t Value & $p>|t|^{*}$ \\
\hline $\begin{array}{l}\text { Coal } \\
\text { Age } \\
\text { Smoking } \\
\text { Coal } \times \text { smoking } \\
\text { adjusted } R^{2}\end{array}$ & $\begin{array}{r}3.64 \\
7.76 \\
3.91 \\
-2.99\end{array}$ & $\begin{array}{l}0.0003 \\
0.0003 \\
0.0001 \\
0.004\end{array}$ & $\begin{array}{r}3 \cdot 53 \\
7 \cdot 86 \\
3 \cdot 28 \\
-1 \cdot 89\end{array}$ & $\begin{array}{l}0.0005 \\
0.0001 \\
0.002 \\
0.06\end{array}$ & $\begin{array}{r}3 \cdot 79 \\
7 \cdot 87 \\
4 \cdot 02 \\
-3 \cdot 15\end{array}$ & $\begin{array}{l}0.0002 \\
0.0001 \\
0.0001 \\
0.002\end{array}$ \\
\hline
\end{tabular}

* Probability of obtaining an absolute value of $t$ as great or greater.

coal-smoking interaction term improved the model slightly, with coal and smoking having a negative interaction (equation 2). Note that the effect of lung coal content on $E$ score must be obtained by using a combination of the coal only and coal $\times$ smoking regression coefficients, as the effect of coal depends on the level of smoking.

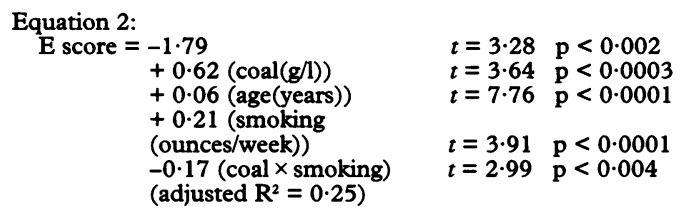

Of the other potential interactions (coal $x$ silica, coal $\times$ age, silica $\times$ age, silica $\times$ smoking, and age $\times$ smoking) none showed a significant effect. Similar results were obtained when the coal and silica contents were expressed in an unadjusted form (as absolute weight per subject) or as a proportion of the dry weight of lung (table 5).

When the 40 non-smokers were considered separately, the positive effect on emphysema score of coal content and age was striking, with these two variables accounting for about two thirds of the variation in emphysema score (equation 3). Silica content of the lungs and all interaction terms did not contribute significantly to the model. The figure shows the univariate association between coal content of the lungs and emphysema for nonsmokers.

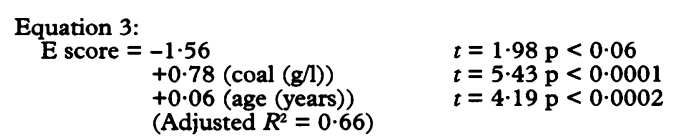

Emphysema score had a highly significant negative relation with $\mathrm{FEV}_{1} \%$ for the 184 subjects who had available $\mathrm{FEV}_{1} \%$ measurements (equation 4). Almost identical results were found when lung coal content was added to the regression model $\left(b_{\text {Escore }}=-7 \cdot 39, t=-\right.$
$6 \cdot 73, \mathrm{p}<0.0001)$, with coal not making a significant contribution to the model $\left(b_{\text {coal }}=\right.$ 2.86, $t=1.00, \mathrm{p}>0.32)$. This relation seemed to be similar for non-smokers, with the low numbers of non-smokers with available $\mathrm{FEV}_{1}$ data (28) probably responsible for the borderline statistical significance of this relation (equation 5).

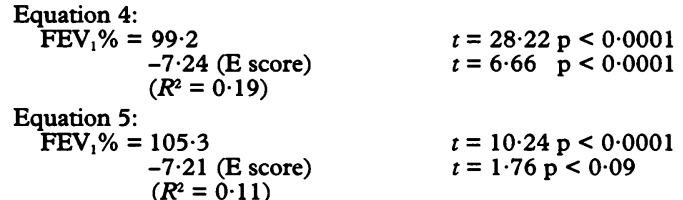

Emphysema score was significantly higher in subjects with pneumoconiotic change (moderate, profuse, or massive) than in sutjects with minimal or no pneumoconiotic changes $(t=4.90, \mathrm{p}<0.0001)$. This relation was independent of coal and silica content of the lungs. Mean $\mathrm{FEV}_{1} \%$ was higher, but not significantly so, in subjects with minimal or no pneumoconiotic change than in those with definite pneumoconiotic change ( $82 \% v 76 \%$; $t=1 \cdot 40, \mathrm{p}>0 \cdot 17)$.

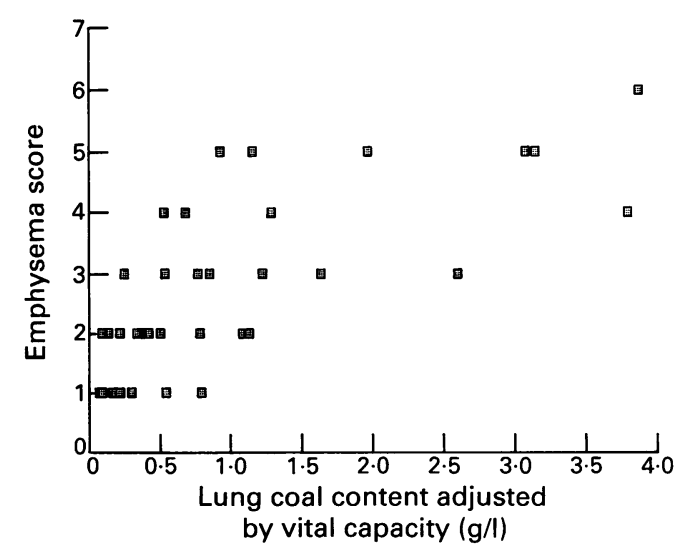

Univariate relation between adjusted lung coal content and emphysema score for lifelong non-smokers $(n=40)$. 


\section{Discussion}

The results show clearly that content of coal in the lungs is quantitatively related to the development of emphysema, taking into account age and smoking. This is true whether the effect of smoking is controlled by regression methods or by examining only lifelong non-smokers. The results indicate that a non-smoking miner with about the average lung coal content would have emphysema involving $7 \%$ to $10 \%$ more of the whole lung mass than a non-smoking person of the same age who was not exposed to coal. The influence of coal seems less pronounced in smokers, perhaps due to a negative interaction between smoking and coal. Although other possible causes of emphysema in coalworkers, apart from coal and smoking, have been suggested, ${ }^{23}$ the high $R^{2}$ term in the regression equation for non-smokers strongly suggests that coal exposure and age are the main determinants of emphysema in non-smoking coalworkers. Biologically plausible mechanisms for a pathological effect of coal on lungs to produce emphysema are now well documented. ${ }^{24} 25$

The analytical technique used in this study measures total coal and silica content of the lungs, which includes both dust in the bronchi and in the parenchyma. This measurement is used as a proxy for the true measure of interest, parenchymal dust, as it is in the parenchyma that any pathological effects that might result in emphysema presumably occur. Therefore, any process (such as dust being trapped in the increased mucus produced in bronchitis) that might alter the proportion of total lung dust in the parenchyma could affect the relation between total lung dust and emphysema. Unfortunately, it is not known how much variation in this proportion might occur due to pathological processes or differences between workers; it is too difficult to dissect out the bronchial tree from the parenchyma to allow separate measurements of dust content in each. Known particle deposition distributions suggest that the parenchymal component would be much larger than the bronchial component, except in very unusual circumstances.

An alternative explanation for the coal and emphysema association found might be that emphysema somehow impairs clearance of dust from the lungs. Greater emphysema would therefore be associated with dust in the lung because of decreased clearance rather than because the dust was causing the emphysema. The effect of emphysema on clearance is uncertain, and there is evidence from animals and humans of both decreased and increased clearance in emphysematous lungs. ${ }^{26-28}$

The strong positive association between age and emphysema found is well documented elsewhere. ${ }^{29}$ An association between smoking and emphysema as found in this study has been well documented for the general community, ${ }^{30}$ in coal miners, ${ }^{7-9}$ and goldminers. ${ }^{13} 14$ The negative interaction between coal and smoking does not have a clear explanation. Perhaps it is because smokers have more bronchitis, ${ }^{30}$ and the increased mucus production traps more coal in the bronchi before it reaches the lung parenchyma. Therefore, for a given amount of measured dust in the lung, more smoking may result in a smaller proportion of dust reaching the parenchyma and correspondingly less emphysema than would otherwise be expected. Alternatively, the negative interaction may be due to a form of competitive inhibition, with the individual effects of coal and smoking having a final common pathway in which the presence of one interferes with the effect of the other. This is plausible, as damage or activation of macrophages or polymorphonuclear leucocytes with subsequent release of elastase or other proteases, is a probable mechanism for the development of emphysema in both smokers ${ }^{31}$ and coal miners. ${ }^{24,25}$ Finally, the relation might simply be a result of statistical associations inherent in this data set rather than a reflection of a true biological phenomenon.

Silica content in the lung was not significantly associated with emphysema in this study. Previous investigators have found conflicting results. One group studying British coalworkers found a negative effect of silica on the prevalence of emphysema in coalworkers. ${ }^{9}$ This was true for lung silica content for subjects with progressive massive fibrosis and for percentage silica of lung dust or percentage silica in the lungs for subjects with any fibrotic lung disease. They postulated that silica induced fibrosis might make emphysematous change less likely. In goldminers exposed to "silica dust", the prevalence of centriacinar emphysema was related to dust exposure level and to the presence of silicosis in one study. ${ }^{14}$ By contrast, an earlier study of goldminers found a positive association between the presence of any emphysema and dust exposure levels, but no significant effect of silicosis. ${ }^{13}$ It is possible that the relation between emphysema and "silica dust" in these two studies was due to some other component of the dust apart from silica, although the dust is known to have had a high silica content. ${ }^{14}$

The lack of an emphysema and silica association in our study may be due to low silica exposures and correspondingly less silica related fibrotic lung disease, even though there was a strong relation between the presence of fibrotic lung disease (mixed coal and silica or silica only disease) and the lung content of silica. The subjects included were mostly recent miners who had a low prevalence of fibrotic lung disease. Of the 259 subjects who had data available on lung histology, $19 \%$ had mixed coal and silica or silica only nodules, with only $34 \%$ of these $(6 \%$ of the total) showing profuse nodularity or massive fibrosis (ILO $2 / 2$ or greater). By comparison, in a study of British coalworkers that showed a negative emphysema and silica association, $79 \%$ of the subjects had some fibrotic lung disease and $33 \%$ were said to have progressive massive fibrosis. ${ }^{9}$ A study of an earlier group of miners from the same mining regions as the subjects used in our study, but exposed to a 
higher concentration of respirable dust, had a much higher prevalence of fibrotic lung disease. Forty eight per cent had mixed nodules and $54 \%$ of these ( $26 \%$ of the total) had ILO $2 / 2$ or greater. ${ }^{12}$ In this group there was a significantly lower prevalence of emphysema in those subjects with mixed nodules than in those with coal only macules, and this difference was especially pronounced in those with profuse mixed nodules. This supports the suggestion that there may be a negative association between silica and development of emphysema. Unfortunately, the lungs of these subjects were not available for the mineral analysis used in this study.

The content of silica in the lungs of subjects in this study was also lower than other studies, both on an absolute and a percentage basis. Our study showed a mean lung silica content of $0.11 \%$ of dry lung weight, compared with $0.35 \%$ in the study of British coalworkers. ${ }^{9}$ The comparable absolute amounts were $0.18 \mathrm{~g}$ and $0.30 \mathrm{~g}$ per subject. Percentage content of coal in the lungs could not be directly compared between the two studies because of differences in the presentation of data, but the mean absolute amount of coal per subject found in our study $(3.9 \mathrm{~g})$ was lower than that found in the British study $(4.9 \mathrm{~g})$. Content of coal in the lungs was an order of magnitude higher than silica content in our study (mean coal $(\mathrm{g} / \mathrm{l})$ : mean silica $(\mathrm{g} / \mathrm{l})$ $=22: 1$ ), similar to the British study, which found a corresponding ratio of about 16:1.

Emphysema score had a highly significant negative relation with $\mathrm{FEV}_{1} \%$ in our study. This result has been found previously in a larger group of coalworkers that included the subjects from our study, ${ }^{11}$ and in other studies of coalworkers. ${ }^{89}$ The emphysema and $\mathrm{FEV}_{1} \%$ relation was independent of coal content in the lungs suggesting that the association was not a consequence of dust exposure independently causing emphysema and a decrease in $\mathrm{FEV}_{1} \%$. The regression coefficient suggests that the emphysema found in coalworkers is of some functional relevance, with an increase of emphysema of $10 \%$ leading to a predicted decrease of $\mathrm{FEV}_{1} \%$ of about $7 \%$. This same negative relation between $\mathrm{FEV}_{1} \%$ and emphysema was suggested in the analysis that included only non-smokers, but the few subjects with available $\mathrm{FEV}_{1}$ measurements make firm conclusions difficult. Recent evidence indicates that occupational exposure to coal dust alone might produce clinically important airways dysfunction, ${ }^{236}$ although this is not accepted by all researchers. ${ }^{45}$ In this study, as the severity of pneumoconiosis increased the severity of emphysema increased. This relation seemed to be independent of dust content of the lungs and suggests a direct pathological connection between pneumoconiosis and emphysema. The $\mathrm{FEV}_{1} \%$ showed a non-significant decline with increased severity of pneumoconiosis. The lack of statistical significance of this relation was possibly due to the limited number of subjects with available $\mathrm{FEV}_{1}$ measurements.

The lung content of coal and silica were highly correlated with each other, as would be expected because most coalworkers were exposed to mixed coal and silica dust. The lung contents of coal and silica were also both highly significantly correlated with years worked at the face, although the correlation coefficients of 0.26 and 0.27 suggest that years worked at the face gives a more qualitative estimate of the lung burden from dust exposure. Years at the face was highly significantly correlated with emphysema score, but not when age was taken into account, presumably because years at the face was acting as a proxy measure of age in the univariate correlations.

Some sources of bias are possible in a study of this type, but, for reasons outlined here, bias is not thought to have been a significant problem. Most of the emphysema found in previous studies of coalworkers was reported to be of the centriacinar type, ${ }^{78}$ with little panacinar emphysema, and this was also the case in the present study. In advanced cases, centriacinar emphysema extended to involve whole lobules and to coalesce between lobules, ultimately involving the whole lung. In accordance with current thinking, ${ }^{32-34}$ we regarded the two types of emphysema as part of a range and hence made no attempt to separately measure panacinar emphysema. Tissue preparation methods were the same for all lung specimens used and emphysema measurements were made by either of two observers with standard techniques, with a high degree of interobserver agreement and blinded to the other variables of interest. Assessment of emphysema by macroscopic measurements has been criticised, ${ }^{32}$ but the technique is widely used ${ }^{35}$ and, in this study, emphysema score had a highly significant negative relation with $\mathrm{FEV}_{1} \%$, as would be expected clinically. The measurements of overall emphysema are therefore believed to be appropriate and reasonably accurate.

Dust analysis was performed with minor modifications of established techniques, there was good agreement between duplicate samples, and analysis was done without knowledge of the emphysema measurements made on each specimen. Lung content of coal and silica can be regarded as the best quantitative estimate of exposure as, once clearance mechanisms are saturated, accumulation of dust in the lungs is probably proportional to further exposure. ${ }^{36}$

Coal and silica contents in the lungs were adjusted by means of predicted vital capacity, which was used as an estimate of lung volume, thereby providing a measure of the concentration of coal and silica in the lung. This adjustment introduces some (presumably non-differential) error. Expressing coal and silica content of the lungs as a proportion of dry lung weight would seem to give an even better measurement of the concentration of dust in the lung. Unfortunately, this measurement can be criticised on the basis that more emphysematous lungs probably contain less total lung tissue. Thus for a given amount of total lung dust, more emphysematous lungs 
would have a higher concentration of dust per dry weight of lung, thereby potentially introducing a spurious positive relation between dust content and amount of emphysema. Conversely, more fibrotic lungs might contain more lung tissue and so introduce an apparent negative relation. Nevertheless, authors have expressed lung dust content on a per dry weight of lung basis, ${ }^{9738}$ and in our study analyses with this measurement for coal and silica produced similar results to the main analyses performed with measures adjusted by predicted vital capacity. The absolute mass of coal or silica (unadjusted) does not give a measure of the concentration of dust in the lung as it does not take into account the fact that bigger lungs will contain more dust than smaller lungs. Therefore, this measure is likely to contain significant non-differential error, although analyses with these unadjusted measures gave similar results to the primary analysis.

The 264 subjects are a subset of a continuous series of 1086 postmortem examinations on coalworkers in New South Wales from 1949 to 1987 . Lung tissue obtained before 1966 is no longer available for mineral analysis. Subjects who had a postmortem examination during the study period 1966-83 but were not included in this study had similar values for the main known variables of interest as subjects who were included. Because the main reason for exclusion of subjects at this stage was inadequate lung specimens it is unlikely that significant bias was introduced because of this exclusion. It is likely that those miners on whom postmortem examinations were carried out had a higher prevalence of lung disease than the overall mining population of the same age during the study period. Lung disease established at postmortem examination would be more likely to attract compensation for the families of the miners than lung disease that was not confirmed pathologically, so families of miners who suspected that they had lung disease are more likely to have agreed to a postmortem examination. There is no reason to believe, however, that selection would have been influenced by severity of emphysema and lung dust content in such a way as to artificially produce the results found.

In conclusion, the results provide strong support for the hypothesis that severity of emphysema in coalworkers is causally related to coal content in the lung and thus to exposure to coal in life. In this regard it is of interest that emphysema has recently become a prescribed disease for underground coal miners in the United Kingdom. ${ }^{39}$ The importance of age and smoking in severity of emphysema is also confirmed. The results do not support a relation between exposure to silica and the development of emphysema. The lung content of silica of subjects may not have been high enough, however, to show the true effect of silica.

The skilled technical assistance of Mr D Moffat (Joint Coal Board) and Dr $K$ White (consultant pathologist) is gratefully acknowledged. The initial work of Drs $K$ Outhred and I
McKenzie of the Joint Coal Board (both now deceased) in establishing the pathology programme is also recognised. We thank the Occupational Medicine, Occupational Hygiene and Toxicology Units (NIOHS), and the Departments of Chemical Engineering, Geology, and Inorganic Chemistry (University of Sydney), for laboratory facilities.

The views expressed in this article are those of the authors and do not necessarily reflect those of the National Occupational Health and Safety Commission.

1 Seaton A. Coal and the lung. Thorax 1983;38:241-3

2 Becklake MR. Occupational exposures: evidence for a causal association with chronic obstructive pulmonary disease. Am Rev Respir Dis 1989;140:s85-s91.

3 Seaton A. Coal, emphysema, and compensation. Br 7 Ind Med 1990;47:433-5.

4 Gee JBL, Morgan WKC. Coalmining, emphysema, and compensation. Br f Ind Med 1991;48:70-2.

5 Morgan WKC. Coal mining, emphysema, and compensation revisited. $\mathrm{Br} \mathcal{F}$ Ind $M$ ed 1993;50:1051-3.

6 Oxman AD, Muir DCF, Shannon HS, Stock SR, Hnizdo E, Lange HJ. Occupational dust exposure and chronic obstructive pulmonary disease. A systematic overview of the evidence. Am Rev Respir Dis 1993;148:38-48.

7 Cockcroft A, Wagner JC, Ryder R, Seal RME, Lyons JP, Andersson N. Postmortem study of emphysema in coalworkers and non-coalworkers. Lancet 1982;ii:600-3.

8 Ruckley VA, Gauld SJ, Chapman JS, et al. Emphysema and dust exposure in a group of coal workers. Am Rev and dust exposure in a grou

9 Ruckley VA, Fernie JM, Campbell SJ, Cowie HA. Causes of disability in coalminers; a clinico-pathological study of emphysema, airways obstruction and massive fibrosis. Edinburgh: Institute of Occupational Medicine, 1989 (Report No TM/89/05).

10 Leigh J, Outhred KG, McKenzie HI, Wiles AN. Multiple regression analysis of quantified aetiological, clinical and post-mortem pathological variables related to respiratory disease in coal workers. Ann Occup Hyg 1982;26: $383-400$.

11 Leigh J, Outhred KG, McKenzie HI, Glick M, Wiles AN. Quantified pathology of emphysema, pneumoconiosis, Quantified pathology of emphysema, pneumoconiosis, and chronic bronch

12 Leigh J. Relationship between emphysema severity and histologic type of pneumoconiosis in coal workers [abstract]. Eur Respir $\mathcal{f} 1992 ; 5: 519 \mathrm{~s}$.

13 Becklake MR, Irwig L, Kielkowski D, Webster I, De Beer M, Landau S. The predictors of emphysema in South African gold miners. Am Rev Respir Dis 1987;135: $1234-41$.

14 Hnizdo E, Sluis-Cremer GK, Abramowitz JA. Emphysema type in relation to silica dust exposure in South African gold miners. Am Rev Respir Dis 1991;143:1241-7.

15 Glick M, Outhred KG, McKenzie HI. Pneumoconiosis and respiratory disorders of coal mine workers of New South Wales, Australia. Ann NY Acad Sci 1972;200. 316-41

16 Gough J, Wentworth JD. Thin sections of entire organs mounted on paper. In: Harrison CV, ed. Recent advances in pathology. 7th ed. London: Churchill Livingstone, 1960:80-6.

17 Heard BE. Pathology of chronic bronchitis and emphysema. London: Churchill Livingstone, 1969:10-13.

18 Guest L. The recovery of dust from formalin-fixed pneumoconiotic lungs: a comparison of the methods used at moconiotic lungs: a comparison of the
SMRE. Ann Occup Hyg 1976;19:37-47.

19 Dodgson J, Whittaker W. The determination of quartz in respirable dust samples by infrared spectrophotometry-I. The potassium bromide disc method. Ann Occup Hyg 1973;16:373-87

20 Lazarus $R$. Lung-function reference values from Victorian power-industry workmen. Med $\mathcal{F}$ Aust 1982;2:121-4.

21 Ferris BG, Anderson DO, Zickmantel R. Prediction value for screening tests of pulmonary function. Am Rev Respir Dis 1965;91:252-61.

22 SAS Institute. SAS System, version 6.03. Cary, NC:SAS Institute, 1987.

23 Kennedy MCS. Nitrous fumes and coalminers with emphysema. Ann Occup Hyg 1972;15:285-300.

24 Brown GM, Donaldson K. Inflammatory responses in lungs of rats inhaling coalmine dust: enhanced proteolysis of fibronectin by bronchoalveolar leukocytes. $B r f$ Ind Med 1989;46:866-72.

25 Rom WN. Basic mechanisms leading to focal emphysema in coal workers' pneumoconiosis. Environ Res 1990;53 16-28.

26 Gross P, Tuma J, de Treville RTP. Emphysema and pneumoconiosis: a comparative quantitation of dust conten of pneumoconiotic rodent lungs with and withou emphysema. Arch Environ Health 1971;22:194-9.

27 Heppleston AG. The pathologic recognition and pathogenesis of emphysema and fibrocystic disease of the lung with special reference to coal workers. Ann NY Acad Sci 1972;200:347-69.

28 Ferin J. Emphysema in rats and clearance of dust particles. In: Walton WH, ed Inhaled particles III, part I, Old Woking: Unwin, 1970:283-92.

29 Ingram RH Jr. Chronic bronchitis, emphysema, and airways obstruction. In: Braunwald $\mathrm{E}$, Isselbacher $\mathrm{KJ}$, wetersdorf RG, Wilson JD, Martin JB, Fauci AS, eds. Harrison's principles of internal medicine. 6th ed. New Harrison's principles of internal medicine.
York: McGraw-Hill Inc, 1987:1087-95.

30 Burrows B. An overview of obstructive lung diseases. Med 
Clin North Am 1981;65:455-71.

31 Cotes JE, Steel J, eds. Chronic bronchitis and emphysema: roles of smoking, occupation and air pollution. In: Workrelated lung disorders. Oxford: Blackwell Scientific Publications, 1990:373-86.

32 McLean A, Warren PM, Gillooly M, MacNee W, Lamb D. Microscopic and macroscopic measurements of emphysema: relation to carbon monoxide gas transfer. Thorax 1992;47:144-9.

33 Gough J. The pathogenesis of emphysema. In: Liebow A, Smith DE, eds. The lung. International Academy of Pathology monograph No 8. Baltimore: Williams and Pathology monograph No

34 Gough J, James WRL, Wentworth JE. A comparison of radiological and pathological changes in coalworkers' pneumoconiosis. Fournal of the Faculty of Radiologists 1950;1:29-39.

35 Thurlbeck WM. Chronic airflow obstruction in lung dis- ease. In: Bennington JL, ed. Major problems in pathology. Vol 5) Philadelphia: WB Saunders Company, 1976; 253-70.

36 Outhred KG. The pneumoconioses. In: Major G, ed. Proceedings, first Australian pneumoconiosis conference. Sydney:1968:1-6.

37 Attfield MD, Vallyathan V, Green FHY. Radiographic appearances of small opacities and their correlation with pathology grading of macules, nodules, and dust burden in lungs. In: Seventh international symposium on inhaled particles. Edinburgh September, 1991;P1.2.

38 Gibbs AR, Pooley FD, Griffiths DM, Mitha R. Silica and silicate pneumoconioses - a pathological and mineralogical study. In: Seventh international symposium on inhaled particles, Edinburgh: September, 1991;\$10.3.

39 Industrial Injuries Advisory Council. Chronic bronchitis and emphysema. Social Security Administration Act 1992. London: Department of Social Security, 1992. 